\title{
5. 治療における血中濃度モニタリング
}

中 野眞 汎*

はじめに

薬物療法適正化のための血中濃度モニタリング は医師の要望と測定機器の進歩により, 多くの病 院で実施されるようになりつつある.

薬物血中濃度の測定法については, すでに 「Phase I から IIIにおける薬物血中濃度測定」 の項で奥村先生が述べておられるので, 本稿の内 容は, 薬物血中濃度モニタリングの必要性からは じめ, 病院薬䬉師としての臨床薬理学的アプロー チをも含めた, やや広い範囲とし, 本シンポジウ ムの主題「我が国における臨床薬理のすすめ方」 の薬学分野からの取り組みを紹介させていただき たい.

\section{1. 薬物血中濃度モニタリングの必要性}

本件は 4 つに分けて考えてみる.

1 ) ナン・コンプライアンス：医師の服薬指示 がどのくらい遵守されているかの調查では, その 遵守率はかなり低い。すなわちナン・コンプライ アンス率が高いことが明らかにされている(中村, 1982)11.

その原因を分析してみると，1つは成人男性に みられるような多忙さのための昼食後の服薬忘れ であり，もう一つは主婦とその保護下にある小児 にみられる薬による有害作用の発現の恐れからの 服薬拒否である. 前者の解決のためには服薬回数 の減少が望まれ, 処方上徐放性製剤への切り換え が必要となる. 後者のためには薬の有害作用のみ が強調された 1 部マスコミに対して一般大衆を対

* 熊本大学医学部附属病院薬剤部

画860 熊本市本荘 1-1-1
象とした薬に関する啓蒙により薬に対する正しい 理解が得られるように努力しなければならないと 感じている. もちろん薬の交付時には十分な服薬 指導もすべきである.

2 ) 個人差: 同じ propranolol $40 \mathrm{mg}$ 錠を 2 錠 ずつ服用した 38 人の患者で血漿濃度に著しい差 が見られたという報告(Sotaniemi et al., 1979)2) に見るように，薬物血中濃度の測定による体内動 態の個人差が次々に明らかにされている.

2-1）吸収：個人差のうちでは, 以前から肝蔵 病と腎臓病による代謝能・排泄能の低下が認識さ れているが吸収過程での個人差も大きいことが, これも血中濃度測定により明らかにされつつあ る.この吸収過程では個人差の一大原因として胃 内容排出挙動の差をあげたい.

胃内容排出挙動には, いくつかのパターンがあ ることが示されている (Clements et al., 1978) 3). すなわち, 比較的急速に胃内容を排出する個人も あれば, 急速に胃内容を排出し始め, 途中で中休 みしてから排出を再開する個人，かなり遅れてし かもゆっくりと胃内容を排出する個人などが考え られる. 熊本大学病院の例でも, digoxin 0.25 $\mathrm{mg}$ 錠 2 錠を 6 人のボランティアに投与後の血清 中濃度曲線の差としても認められた（Fig. 1, 渋 田ら, 1980 $)^{4)}$. この胃内容排出挙動は食事によっ ても影響されるため, 投与後の吸収速度が食事に よって遅くなり, 薬物の種類によっては bioavailability の大きさも影響を及ぼされる．例えば, ampicillin カプセルの場合, 食後投与時には血清 中濃度が遅く上昇し始め, 血清中濃度曲線下面積 (bioavailability) も絶食時投与よりも小さかっ た (Welling et al., 1977) ${ }^{5}$. 


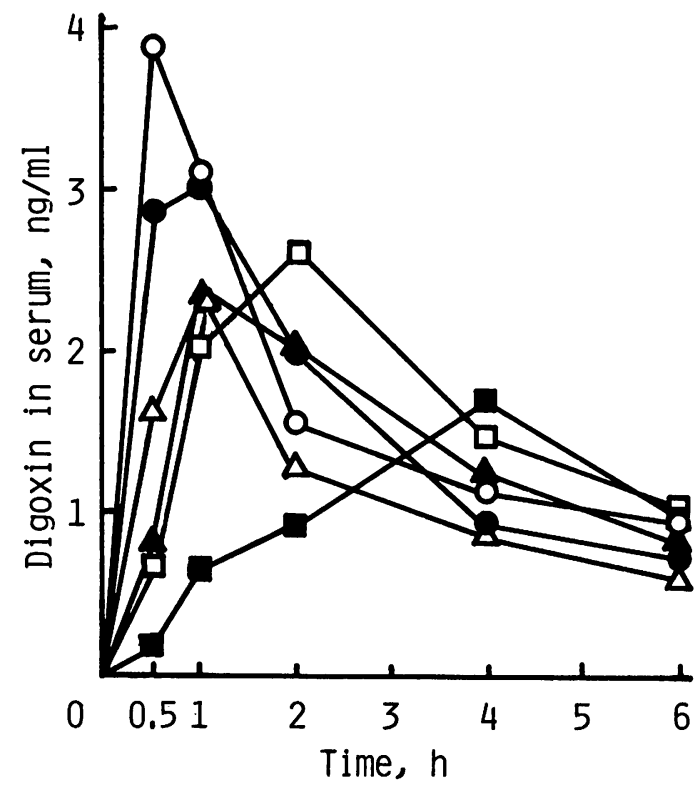

Fig. 1 Individual serum concentration profiles of digoxin after single oral administration of two $0.25 \mathrm{mg}$ tablets to healthy volunteers.

逆に，薬物が疎水性のため水に溶けにくく bioavailability に差が生じやすい phenytoin など では，食後投与時には胆汁酸分泌による界面活性 作用のために薬物が良く溶け bioavailability が 絶食時投与よりも大きくなることを我々は確認し た (Sekikawa et al., 1980)6).

2-2）代謝：代謝における個人差については, 遺伝的素因による場合と肝臓病による代謝機能の 低下がある.前者は遺伝的な酵素活性の差であり， アセチル化酵素活性, 水酸化酵素活性などでも活 性が大きなグループと小さなグループに分けられ る. 繰り返し投与時には大きな血中濃度差として 現れるので血中濃度測定によりこの差を見いださ なければ危険な場合もある。

肝臓病による代謝機能低下については, 慢性肝 臓疾患では, labetalol の血漿中濃度が健常者よ り平均 4 倍以上も高かったという報告に見ること ができる (Homeda, et al., 1978） 7).

2-3）排泄：排泄挙動が腎臟病により差が生じ ることは良く知られているので，ここでは言及し ない。
3 ）複数薬物併用による相互作用：薬物動態学 的には, 吸収, 分布, 代謝, 排泄, さらに薬力学 的にはレセプターでの相互作用が考えられるが， 代謝過程に限定しても代謝阻害による血中濃度上 昇と代謝促進による血中濃度下降が考えられる. 前者の例として cimetidine による代謝酵素阻害 がかなり多くの薬物で見いだされており, cimetidine $300 \mathrm{mg} 6 \mathrm{hr}$ ごとの投与時には, theophylline の動態も変化し, 単独投与時よりも血清中濃度の 有意の上昇が見られた (Mulkey et al., 1983) $)^{8}$. 後 者の例としては, phenytoinを 10〜15日間投 与した場合，その前後での theophylline の消失 速度が大きく変化した例をあげることができる (Marquis et al., 1982)9.

4 ) 製剤差: 同じ薬物の同じ製剤でも異なる製 造メーカーによる処理工程の差，さらに同じ薬物 の同じメーカーの品でも剤形の違いにより, 溶解 速度さらには bioavailabilityに差が生じうる。 前者の例は報告も多い，後者の例としてはdigoxin $0.5 \mathrm{mg}$ の錠剂投与時と，散剤投与時に，血 清中濃度に有意差が見られた熊本大学病院の検討 例がある(近藤ら，1981）吕。

\section{2. 処方と服薬指示の適正化}

1.に述べたように, 薬物血中濃度モニタリン グを必要とする因子は多く，ボランティア・患者 を問わず，同じ薬物を同じ条件で服薬しても，実 際に大きな個人差を観察する。これにもかかわら ず，現実の薬物療法においては，薬物の種類・剤 形の種類の違いによることなく，1日 3 回食後服 薬の指示がなされ続けているのは，個人間さらに は個人内でも時間による血中濃度差を拡大してい ることになろう。

1 ）投与回数の見直し：1日 3 回, 毎食後服薬 では, その薬物の平均半減期から予想して, 朝方 に有効濃度以下に下がりうる薬物もあり，この種 の薬物については，就寝前をも加えた 1 日 4 回服 薬が考虑されるべきである，逆に薬物の平均半減 期から予想して, $12 \mathrm{hr}$ 程十分に有効濃度を保ち うる薬物については, 朝夕 2 回服楽にしたほうが コンプライアンスも良好となり，より確実な薬物 
コンプライアンスも良好となり，より確実な薬物 療法が可能と考えられる.

2 ）食後服薬の是非：服薬時間についても，亡゙ んな薬物も食後服用とするのは不合理である，消 化管粘膜に対し刺激性のある薬物では食後服薬が 望ましかろうが，さもなければ，その薬物の有効 性を得やすい投与時間を再検討すべきであろう.

以上の投与間隔・食事との前後関係の適正化 は, 薬物動態学的研究が発展するにつれ, データ が集積されつつあるので, 合理的な方向へ改善し つつあると思うが，この種の問題は次の血中濃度 モニタリング以前に解決すべき問題と考えてい る.

\section{3. 薬物療法適正化のための薬物血中濃度モ二} タリング

1 ) 特定薬剂治療管理料: 薬物血中濃度モ二夕 リングに基づいて投薬管理がなされたとき, 診療 報酬の請求がいくつかの薬物で認められたこと は,この投薬管理の重要性が技術料の形で評価さ れたことを意味し，大きな前進と考えられる.

2 ) 血中濃度モニタリングの必要な薬物：血中 濃度モニタリングを必要とする薬物としては Tab. 1 のような性格のものがあげられ，かなり の数の薬物がその対象となりうるが, 具体例とし て抗けいれん薬, 循環器系薬物などをあげること ができる.この中で特定薬剤治療管理料の請求が 認められている薬物は, 抗けいれん薬, lithium, digitalis 類, アミノ配糖体のみであり, digitalis 類以外の循環器系薬物, 抗癌薬 methotrexateな どもまだ請求が認められていないので, 保険収載 拡大を要望したい.

3 ）血中濃度測定例: 通常の薬物血中濃度モ二 タリングは, 免疫学的定量法が一般的であるが, 免疫学的定量試薬が市販されていない場合, これ とは別に積極的意味において代謝物をも含めて同 時に分離定量し, 薬物の体内動態を一層くわしく 把握したい場合には,クロマトグラフィーが用い られる. 熊本大学病院の高速液体クロマトグラ フィ一使用例として, 小児および成人脳性麻痺患 者における筋弛緩薬 dantrolene 投与量と血中濃
Tab.1 血中濃度モニタリングの必要な薬物
1. 効果と濃度との間に関渾がある
2. 治療濃度範囲が狭い
3. 体内動態の個人差が大きい
4. 濃度と投与量の関係が非線形性を示す
5. 病態・年歯差で体内動態が変化する
6. 併用薬物により影響を受ける
7. 服薬上の誤りのおそれがある

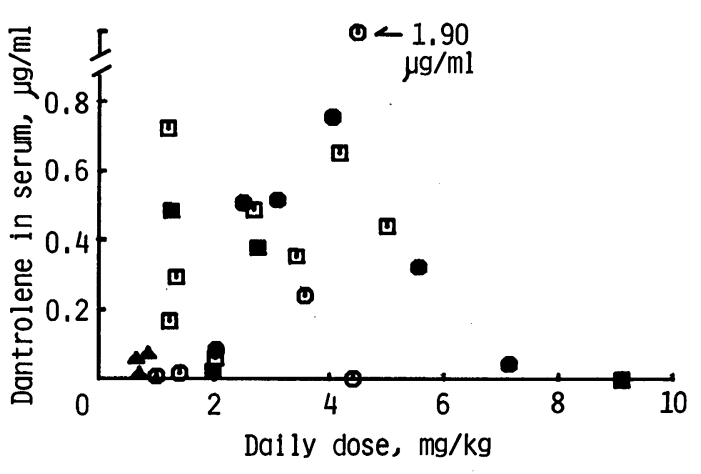

Fig. 2 Plot of daily dose versus $\mathrm{C}_{\min }^{\mathrm{ss}}$ of dantrolene at steady state. Key : $\bigcirc$; older than $15 \mathrm{yr}$ and administering t.i.d. : O younger than or equal to $15 \mathrm{yr}$ and administering t.i.d. : $\square$; older than $15 \mathrm{yr}$ and administering b.i.d. : Dyounger than or equal to $15 \mathrm{yr}$ and administering b.i.d. : $\triangle$; older than $15 \mathrm{yr}$ and administering once daily.

度の関係を示す (Fig. 2, Inotsume et al., 1984) $)^{11)}$. さらに精神病患者における haloperidol 投与量と 血中濃度の関係も示す (Fig. 3, 猪爪ら, 1984) ${ }^{12)}$. これらいずれの場合にも, 投与量と血清中濃度の 相関係数は低かったので, この現実の認識のもと に，各患者への投薬管理がなされつつある.

4 ）投薬管理への反映：血中濃度モニタリング の結果は, 投与設計変更の形で処方之服薬指導の 両面で反映されなければならない.

\section{4. 病院薬剂師の臨床薬理分野での取り組み}

薬剤師は病院内での医薬品の取り扱いの適正化 を目指して, 医師の処方に基づく正確な調剂と注 射剤の支給を行っているが，その他の任務として 次の取り組みもしている.

1 ) 医薬品の品質評価：病院で採用する医薬品 


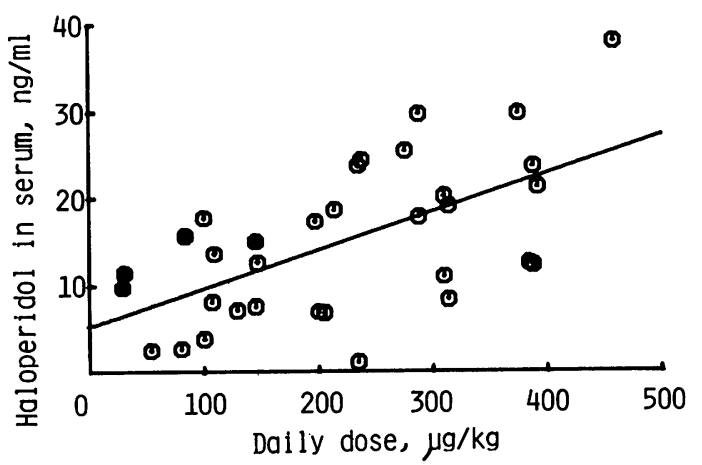

Fig. 3 Plot of daily dose versus serum concentrations of haloperidol in psychotic patients.

Key : $\bigcirc$; Patients younger than or equal to 60 yr: ; Patients older than $60 \mathrm{yr}$

としては，より良質の銘柄を選んで購入するため に，購入申請がなされた医薬品については，同種 医薬品とともに医薬品試験室で製剤学的面からの 品質評価を行い, その試験結果は薬事委員会へも 提出されて, 採用医薬品選定時の資料としている.

2 ) 薬事委員会への資料作成：熊本大学病院で は，薬事委員会は毎月 1 回定期的に開かれ，診療 科の代表として科長 2 名, 副科長 2 名, 医局長 4 名, 薬剤部の代表として部長と副部長, それと事 務部長が薬事委員として出席し, 薬剤部長が委員 長・議長を勤めている，薬事委員会では，(1)新規 購入申請医薬品，(2)試用医薬品，(3)臨床試験申請 治験薬，(4)特定医薬品，(5)その他の順で審議を進 める、薬剤部で医薬品情報室を中心に調査した資 料（Tab. 2) を薬事委員会に提出して, 審議の参 考にしている.

3）院内特殊製剂：特殊な患者の治療を目的と するため，市販品として得られない製剤は，医師 の要請により，薬剤部の製剤室で調製し病棟に供 給している.

4 ) 服薬指導: 適切な処方, 正確な調剤も, そ の調剤薬が正しく使用されなければ十分な効果を 期待できないので, 調剤薬交付時には, 患者の知 識に応じて服薬指導に努めている.

5 ) 医学教育: 熊本大学では, 医学部專門 3 年 生に対し臨床薬剤学という講義・実習を担当して
Tab. 2 薬事委員会のための資料

新規購入申請医薬品の位置付け

特徵

関連医薬品の使用状況

品質評価

医薬品情報提供状況

臨床試験用治験薬の安全性

動物での安全性試駼結果

臨床第 1 相, 第 2 相での有害作用

いる.

5-1）講義：熊本大学では専門 1 年次に, 薬理 学講義の中で, 臨床薬理学の基本を履修している が, 臨床薬剤学での基本的な考え方は, 処方は患 者と治療薬についての各面からの知識の具体化, すなわち投与経路, 剤形, 投与後の pharmacokinetics, 病態時の pharmacokinetics, 薬物相互作 用, 医薬品副作用情報などの総合的知識に基づ いて, 院内採用の医薬品から選んで, 患者の病態 にふさわしいものとすべきという考えにおいてい る.

5-2）薬凨業務見学：医学生が班に分かれて, 薬剤部内の全業務, すなわち調剤室, 医薬品管理・ 注射剤支給室, 製剤・無菌製剤室, 医薬品情報室, 試験研究室の業務を見学し, 薬剤部門の機能を見 て理解する機会を持っている.

5-3）実習：時間数不足のため不十分であるが, 特殊な製剤の例としての発泡腸溶錠の溶解挙動の 観察と，投与設計のためのマイクロコンピュータ を用いた血中濃度曲線のシミュレーションを実施 している.

これらの試みにより, 将来臨床医として, より 良い処方を考え，また患者に副作用が発生したと き，医薬品情報室へ相談に来やすい環境が生まれ ることを願っている.

6 ）薬剤師教育：薬凨師の臨床薬理学分野の教 育に関しては,薬の専門職としての期待に反して, 現実にはその期待にこたえるにふさわしいカリ キュラムが組まれていない.しかしニーズは感じ ているので, 1 部の大学ではこの方向への努力が 
Tab. 3 医師との共同研究例

1. 筋弛緩薬の体内動態

2. 精神病治療薬の体内動態

3. 抗けいれん薬の体内動態

4. CAPD施行時の薬物の体内動態

5. 抗癌薬マイクロスフィアの調製と臨床的検討

6. 抗癌薬エマルションの調製と有用性検討

7. 活性炭ビーズの調製と薬物中毒解毒剂とし ての検討

続けられていることも事実であり，卒後研修さら には採用後の教育としてなされている．現実には 1 人薬剤師の病院もあり，ここに新卒者が就職す る場合には先輩が居ないため採用後教育の実施が 難しいので卒前・卒後研修が必須である.

7 ) 研究：医師が診療と研究を両立させている ように，医療のパートナーとしての薬剤師も薬剤 業務の他, 薬物療法の改善につながる研究に取り 組むべきとの方針のもとに，研究をしている． 1 つの方向は, 薬剤師自身の発想から開始した研究 テーマであり，他は医師の誘いもあって共同研究 の形で進行中のものである (Tab. 3).

薬凨師は新しい製剤を調製する技術，体液中薬 物を分離定量する技術などをもっているので，医 師の生理解剖的知識，外科的技術，そして患者の 病態についての知識と組み合わせ，互の長所を発 揮し合えば，薬物療法の改善に一層寄与できると 考えられるので，この面での協力はさらに発展さ せたいと願っている.

\section{おわりに}

日本では医学教育における臨床薬理学の進展が 遅れているといわれる以上に，薬学教育での臨床 薬理学的教育は遅れている。医師は診断をし，治 療の 1 方法として薬物療法を選ぶわけだが, 薬剤 師は本来薬物療法の専門家であるとすると, 期待 と現実との差はずい分大きいことになる，アメリ カなどでは早くからこの差が認識され, 薬学教育 カリキュラムの再編成が行われた。

薬物療法においては，正しい診断に基づき，そ
れぞれ薬理作用とともに有害作用の可能性をも 持った薬物群から最適の薬が選択され，投与量 ・ 投与間隔の管理がなされると，治療はずっと確実 となり, 病気の治療に必要な期間は確実に短縮で きると考えられている．十分モニタ一された薬物 療法がなされるならば,過剩投与自体はもちろん， これに原因する薬原病の発現も減少するはずであ るから，薬物療法に関する医療費は少なくてすむ はずである. しかしその前提として，医師が薬物 療法に一層慎重となり，パートナーとしての薬剤 師も合理的な薬物療法に充分協力できる実力を養 わなければならないとその責任を感じている.

\section{文 献}

1) 中村仁：高血圧患者の管理. Medicina, 19： 2004-2005 (1982).

2) Sotaniemi, E. A., Anttila, M., Pelkonen, R. O. et al. : Plasma clearance of propranolol and solalol and hepatic drug-metabolizing enzyme activity. Clin. Pharmacol. Ther., $26: 153-161$ (1979).

3) Clements, J. A., Heading, R. C., Nimmo, W.S. et al. : Kinetics of acetaminophen absorption and gastric emptying in man. Clin. Pharmacol. Ther., $24: 420-431$ (1978).

4）渋田達幸, 黒岩 信, 近藤幸裕ほか：ジゴキシ ン錠の互換性. 病院薬学, 6:120-126 (1980).

5) Welling, P. G., Huang, H., Koch, P. A. et al. : Bioavailability of ampicillin and amoxicillin in fasted and nonfasted subjects. J. Pharm. Sci.,66 : 549-552 (1977).

6) Sekikawa, H., Nakano, M., Takada, M. et al. : Influence of dietary components on the bioavailability of phenytoin. Chem. Pharm. Bull., 28 : 2443-2449 (1980).

7) Homeda, M., Jackson, L. and Roberts, C. J. C. : Decreased first-pass metabolism of labetalol in chronic liver disease. Br. Med. J., 2 : 10481050 (1978).

8) Mulkey, P. M., Murphy, J. E. and Shleifer, N. $\mathrm{H}$.: Steady-state theophylline pharmacokinetics during and after short-term cimetidine administration. Clin. Pharm., $2: 439-441$ (1983).

9) Marquis, J. -F., Carruthers, S. G., Spence, J. D. et al. : Phenytoin-theophylline interaction. N. Eng. J. Med., 307 : 1189-1190 (1982). 
10)近藤幸裕, 黒岩信, 有森和彦ほか：ジゴキシン 製剤間のバイオアベイラビリティについて，病 院薬学, 7 : 153-157 (1981).

11) Inotsume, N., Higashi, A., Matsukane, I. et al. : Relationship between serum concentration and daily dose of dantrolene in cerebral palsy patients. Submitted for publication.

12）猪爪信夫, 松永哲夫, 中野眞汎: 精神病患者に おけるハロペリドール投与量と血清中濃度の相 関性. 未発表データ. 